\title{
The Political Economy of Liberal Democracy
}

\section{Faculty Research Working Paper Series}

\section{Sharun Mukand}

University of Warwick

\section{Dani Rodrik}

Harvard Kennedy School

\section{September 2015}

\section{RWP15-052}

Visit the HKS Faculty Research Working Paper Series at:

https://research.hks. harvard.edu/publications/workingpapers/Index.aspx

The views expressed in the HKS Faculty Research Working Paper Series are those of the author(s) and do not necessarily reflect those of the John F. Kennedy School of Government or of Harvard University. Faculty Research Working Papers have not undergone formal review and approval. Such papers are included in this series to elicit feedback and to encourage debate on important public policy challenges. Copyright belongs to the author(s). Papers may be downloaded for personal use only. 


\title{
Acknowledgments
}

This paper was written at the Institute for Advanced Study, to which we are grateful for support. We also thank Carles Boix, William Ferguson, Sumon Majumdar, JanWerner Müller, and Ira Katznelson for helpful suggestions and members of the School of Social Science lunch table for useful discussions.

The views expressed herein are those of the authors and do not necessarily reflect the views of the Harvard Kennedy School or the National Bureau of Economic Research.

(C) 2015 by Sharun Mukand and Dani Rodrik. All rights reserved. Short sections of text, not to exceed two paragraphs, may be quoted without explicit permission provided that full credit, including $\odot$ notice, is given to the source.

\begin{abstract}
$\underline{\text { Abstract }}$
We distinguish between three sets of rights - property rights, political rights, and civil rights - and provide a taxonomy of political regimes. The distinctive nature of liberal democracy is that it protects civil rights (equality before the law for minorities) in addition to the other two. Democratic transitions are typically the product of a settlement between the elite (who care mostly about property rights) and the majority (who care mostly about political rights). Such settlements rarely produce liberal democracy, as the minority has neither the resources nor the numbers to make a contribution at the bargaining table. We develop a formal model to sharpen the contrast between electoral and liberal democracies and highlight circumstances under which liberal democracy can emerge. We discuss informally the difference between social mobilizations sparked by industrialization and decolonization. Since the latter revolve around identity cleavages rather than class cleavages, they are less conducive to liberal politics.
\end{abstract}




\section{Introduction}

By many measures, democracy has conquered the world. Since the fall of the Berlin Wall in 1989, the number of democracies has risen rapidly and cross-national tabulations suggest that, for the first time in history, more countries now qualify as democracies than as nondemocracies (Figure 1). Moreover, the discrediting of fascism and communism means that democracy has no serious ideological competitors at present. Democracy, as a form of political rule, has become a true global norm.

While the spread of democracy is something to cheer about, the majority of today's democracies are electoral rather than liberal democracies. That is, they are political regimes which allow political competition and generally fair elections, but exhibit considerable violations in the civil rights of minority and other groups not in power. For example, Hungary, Ecuador, Mexico, Turkey, and Pakistan are all classified as electoral democracies (according to the Freedom House1). But in these and many other countries, harassment of political opponents, censorship or self-censorship in the media, and discrimination against minority ethnic/religious groups run rampant.

Consider some examples from the OECD club of democracies. In Hungary, "Roma and other minorities have become frequent targets of harassment and of hate speech." In Croatia, the judicial system not only "moves slowly," but "displays an institutional bias in favor of ethnic Croat suspects." Israel exhibits a wide range of civil-rights violations "related to minority rights such as those accorded non-Jewish citizens, particularly Arab citizens, women's rights, and regarding civil protest." In Mexico, "in practice the Mexican military and other security forces are notorious for breaching human rights and the courts do not provide adequate protection." In Turkey, "the rights of the defense, lengthy pre-trial detention and excessively long and catchall indictments" constitute major problems facing opponents of the government and members of the Kurdish minority. ${ }^{2}$ Elsewhere, in countries such as Russia and Venezuela, rights violations are even more blatant, even though elections remain in principle free and competitive.

Fareed Zakaria coined the term "illiberal democracy" for political regimes such as these that hold regular elections but routinely violate rights (Zakaria 1997). More recently, political scientists Steve Levitsky and Lucan Way (2010) have used the term "competitive authoritarianism" to describe what they view as hybrid regimes between democracy and autocracy. Zakaria and others note that democracy developed in Western Europe out of a liberal tradition which emphasized individual rights and placed limits on state coercion. In Britain, France, Germany, and even the United States, mass franchise arrived only after liberal thought had become entrenched. Most of the world's new democracies, by contrast, emerged

\footnotetext{
${ }^{1}$ Freedom House, List of Electoral Democracies, downloadable from https://freedomhouse.org/reporttypes/freedom-world\#.VVIZc5PVEZw.

${ }^{2}$ The quotes come from the 2014 Civil Rights and Political Liberties Report (Bertelsmann Stiftung 2014).
} 
in the absence of a liberal tradition and did little to foster one. As the shortcomings of these democracies have become more evident, it has become commonplace to talk about a "democratic recession" (Diamond 2015).

We provide in this paper a taxonomy of political regimes, distinguishing in particular between electoral and liberal democracy. We take the main distinctive feature of a liberal regime to be the restraints placed on those in power to prevent discrimination against minorities and ensure equal treatment. ${ }^{3}$ The restraints can be legal or administrative; they can be maintained by constitutional strictures or self-enforcing agreements. What matters is that these checks, which we associate with "civil rights" for short, are effective in practice. Our focus is squarely on these missing restraints - the relative weakness of civil rights - in illiberal electoral democracies.

We argue that the failure to protect minority rights is a readily understood consequence of the political logic behind the emergence of democracy. What requires explanation is not the relative paucity of liberal democracy, but its existence - rare as it may be. The surprise is not that few democracies are liberal, but that liberal democracies exist at all.

To make our point, we distinguish specifically between three sets of rights: property rights, political rights, and civil rights. We define these as follows:

- Property rights protect asset holders and investors against expropriation by the state or other groups.

- Political rights guarantee free and fair electoral contests and allow the winners of such contests to determine policy subject to the constraints established by other rights (when provided).

- $\quad$ Civil rights ensure equality before the law - i.e. non-discrimination in the provision of public goods such as justice, security, education and health.

We classify political regimes according to which (combination) of these rights are provided. In dictatorships, it is only the property rights of the elite that are protected. Classical liberal regimes protect property and civil rights, but not necessarily electoral rights. Electoral democracies, which constitute the majority of present-day democracies, protect property and political rights, but not civil rights. Liberal democracies protect all three sets of rights. Note that we operationalize the non-discrimination constraint under liberalism as equal treatment by the state in public goods provision in different domains - legal, religious, educational, etc.

\footnotetext{
${ }^{3}$ There is no single definition of liberalism. But as we discuss in section $\mathrm{V}$ below, historically liberalism grew out of opposition to royal privilege and to discrimination against religious minorities. Most definitions emphasize that in a liberal democracy there are built in protections for the individual/minority against the tyranny of the ruler (the sovereign or the electoral majority, as the case may be). Classical liberals such as John Stuart Mill were preoccupied with the "tyranny of majority" that they feared electoral democracies would produce.
} 
Each one of these rights has a clear, identifiable beneficiary. Property rights benefit primarily the wealthy, propertied elite. Political rights benefit the majority - the organized masses and popular forces. And civil rights benefit those who are normally excluded from the spoils of privilege or power - ethnic, religious, geographic, or ideological minorities.

When the propertied elite can rule on their own they establish an autocracy that protects their (property) rights and little else. This has been the usual outcome throughout the long arch of history. Mass democracy, on the other hand, requires the emergence of organized popular groups that can challenge the power of the elites. In the $19^{\text {th }}$ and $20^{\text {th }}$ centuries, processes such as industrialization, world wars, and de-colonization led to the mobilization of such groups. Democracy, when it arose, was typically the result of a quid pro quo between the elites and the mobilized masses. ${ }^{4}$ The elites acceded to the masses' demands that the franchise be extended (usually) to all males regardless of property qualifications. In return, the newly enfranchised groups accepted limits on their ability to expropriate property holders. In short, electoral rights were exchanged for property rights. ${ }^{5}$

The defining characteristic of this political settlement is that it excludes the main beneficiary of civil rights - the dispossessed minorities - from the bargaining table. These minorities have neither resources (like the elite) nor numbers (like the majority) behind them. So they do not have something to bring to the table, and cannot make any credible threats. The political logic of democratization dictates the provision of property and political rights, but not civil rights. As we formalize in section III, the provision of civil rights is costly to the majority and largely unnecessary for the elite (who can pay for their own collective goods by extracting a surplus from the masses). Therefore the political settlement is one that favors electoral democracy over liberal democracy.

By distinguishing explicitly among three groups and three associated sets of rights, our framework helps explain why liberal democracy is such a rare beast. But liberal democracies do exist, and the question is how they can ever be sustained in equilibrium. We discuss several circumstances that can mitigate the bias against civil rights in democracies.

\footnotetext{
${ }^{4}$ There is an alternative strand of theorizing that views democratization as the result of inter-elite bargaining. For a recent model in that tradition that addresses a puzzle similar to ours - why and when do we get a "minimal" democracy characterized by competitive elections only - see Bidner et al. (2015).

${ }^{5}$ This is essentially the account of the emergence of democracy that is provided, for example, in Acemoglu and Robinson (2009). See also Dahl (1971), Przeworski (1991), Rueschemeyer, Stephens, and Stephens (1992), and Boix (2003) among others. In some of these works, the pact is implicit. Once the franchise is extended to the masses, there must be limits to how much the majority can redistribute to itself; otherwise the tendency would be for the elite to be fully expropriated.
} 
First, there may not be a clear, identifiable cleavage - ethnic, religious, or otherwise that divides the majority from the minority. In highly homogenous societies, the "majority" derives few benefits from excluding the "minority" from public goods and suffers few costs from providing equal access. This may account for the emergence of liberal democracy in Sweden during the early part of the $20^{\text {th }}$ century or in Japan and South Korea more recently.

Second, the two cleavages that distinguish the majority from the minority and the elite from the non-elite may be in close alignment. In such a case, the elite will seek both property and civil rights as part of the political settlement with the majority. Think, for example, of the position of the white minority government in South Africa prior to the transition to democracy in 1994.

Third, the majority may be slender and need the support of the minority to mount a serious challenge to the elite. Or there may be no clear-cut majority, with society characterized by a preponderance of cross-cutting cleavages. In these cases, repeated game incentives may ensure that each group recognizes the rights of others in return for its rights being protected by them. Lebanon's "consociational" democracy may have been an example of this, before differential population growth and outside intervention upset the pre-existing balance of power among different religious denominations.

As these examples make clear, two societal cleavages play a crucial role in our story. First, there is the divide between the propertied elite and the poor masses. This is largely an economic divide and is determined by the division of land, capital and other assets in society, as well as access to the opportunities for accumulating those assets. Standard class-based accounts of the dynamics of political regimes emphasize primarily this cleavage. Second, there is a cleavage between what we call a majority and a minority. This particular divide may be identity based, deriving from ethnic, religious, linguistic, or regional affiliations. Or it may be ideological - as with secular modernizers versus religious conservatives in Turkey, and Westernoriented liberals versus traditionalists in Russia. (We will call this second cleavage an "identity" cleavage for short, but it should be kept in mind that the relevant majority-minority cleavage will run often on ideological lines.) These two cleavages may align (as they did in South Africa), but more often than not, they will not. Their divergence is what allows us to make an analytical and substantive distinction between electoral and liberal democracy.

In our formal model, the majority-minority split exerts a variety of influences on the prospects for liberal democracy. First, and most crucially, it makes the majority favor electoral over liberal democracy. By discriminating against the minority, the majority can enjoy more public goods for itself. But there are effects that go in the opposite direction too. Under some circumstances, the split can make the elite favor liberal democracy. We identify two such consequences. First, the rate of taxation is generally lower under liberal democracy as the 
majority reap fewer benefits from redistributive taxation when they have to share public goods with the minority. So the elite may support liberal democracy when the income/class cleavage is very deep. Second, when the elite's identity aligns with that of the minority, the elite have a direct stake in civil rights too. These channels can produce a rich mix of results. We will show how they interact in a benchmark version of our model.

Even though our model treats them parametrically, the class and identity cleavages are themselves the product of historical and economic developments. In section $\mathrm{V}$, we discuss the roles that these two cleavages have played in democratic transitions in history and across different kinds of countries. We emphasize both ideational and material determinants. On the ideational front, we focus on the evolution of liberalism in the West and its "compromise" with mass democracy and the expansion of the franchise. On the material side, we emphasize longterm economic and social processes - such as industrialization and decolonization - that served both to create and temper, at different times, the cleavage between elites and non-elites.

We suggest that the differential fortunes of liberal democracy in Western Europe and the developing world are related to the nature of dominant cleavages at the time of the social mobilization that ushered in democracy. In the West, the transition to democracy occurred as a consequence of industrialization at a time when the major division in society was the one between capitalists and workers. In most developing nations, on the other hand, mass politics was the product of decolonization and wars of national liberation, with identity cleavages as the main fault line. Our model suggests that the second kind of transition is particularly inimical to liberal democracy. It would take us far too afield to develop all these historical dynamics, which are the subject of a huge literature. We will nevertheless provide a brief overview and a few country vignettes to emphasize the usefulness of our particular framework.

The main innovation in our paper is to unpack the concepts of "democracy" and "liberalism" and to give civil rights an analytical standing co-equal to property rights and political rights. To see the difference this makes, it is useful to compare our approach with standard accounts of the emergence of democracy and liberalism.

The conventional treatment of democracy in the analytical political economy literature focuses on the conflict between a wealthy elite and the organized masses (see for example Przeworski, 2005 or Acemoglu and Robinson, 2009). This approach tends to bundle civil rights with political rights. It provides an explanation for the origins of electoral democracy, but has little to say on the provision of civil rights, when it takes place. ${ }^{6}$ Standard accounts of the emergence of liberalism (which we review in section V), on the other hand, tend to bundle civil

\footnotetext{
${ }^{6}$ As Acemoglu and Robinson note $(2009,26)$, in their framework a transition to democracy "shifts future political power away from the elite to the citizens, thereby creating a credible commitment to future pro-majority policies" (emphasis in the original). Pro-majority policies, by their very nature, will discriminate against powerless minorities.
} 
rights with property rights (as in Marshall 1949 or Fawcett 2014). They evade the puzzle of why a society run by liberal elites would provide broad civil rights when the beneficiaries of such rights are predominantly among the non-elites. The weakness of the political legs on which civil rights rest has been obscured by both kinds of bundling. In both cases, the result has been the failure to ask the question, "where do civil rights come from?"

Another contribution of the paper is that we provide a parsimonious taxonomy of political regimes, both democratic and non-democratic. We accomplish this by distinguishing among three groups (elite, majority, minority) and three kinds of rights (property, political, civil) associated with various modes of taxation and public-goods provision (who determines the tax rate, who pays the taxes, and how the public good is targeted). These distinctions allow us to capture a wide variety of outcomes. The resulting taxonomy should be of independent interest, beyond our focus on liberal democracy.

The outline of the paper is as follows. We first present our taxonomy of political regimes, based on the three-fold distinction of rights we just discussed (section II). We next sketch a simple formal framework to help us think through the circumstances under which liberal democracy, as distinct from illiberal or electoral democracy, becomes politically sustainable (sections III and IV). In the penultimate section (V), we relate our framework to the literature on the history of liberalism and democracy and provide specific country illustrations. In section VI, we conclude.

\section{A Taxonomy of Political Regimes}

We define liberal democracy as a regime in which civil rights are provided in addition to electoral and property rights. We model civil rights in turn as the non-discriminatory provision of public goods. We interpret the relevant public goods broadly, including justice and freespeech rights as well as education, health, and infrastructure. What sets liberal democracy apart from electoral democracy in our framework is that an elected government cannot discriminate against specific individuals or groups when it administers justice, protects basic rights such as freedom of assembly and free speech, provides for collective security, or distributes economic and social benefits.

Our treatment has the advantage that it provides a tractable approach for modeling liberal democracy and distinguishing it from other political regimes. Thinking of liberalism broadly as non-discrimination allows us to sidestep debates about what are the "essential" characteristics of liberalism. The principle of non-discrimination captures a substantial number of liberalism's characteristics, even if not all of them. Our formulation is flexible enough to encapsulate individual and minority rights - an individual is a minority group of size 1 . It applies to a variety of different contexts - non-discrimination in the administration of justice 
(right of habeas corpus for an individual or aggrieved minority), access to education (black girls being allowed to attend schools in Alabama in the 1960s), use of public infrastructure (free access by South African blacks to parks or public transportation), or right to free speech (press freedom for Kurdish newspapers in Turkey). Furthermore, our emphasis on public goods means that we focus on an outcome that is sufficiently general that it can be applied in different country, cultural and historical contexts.

Our distinction between electoral and liberal democracies relies on the presumption that free and fair elections - the hallmark of electoral democracy - can be separated from equal treatment and non-discrimination - the hallmarks of liberalism. It is possible to have one without having the other. This presumption can be criticized. It may be difficult at times to disentangle certain civil rights from political rights. In particular, it can be argued that elections cannot be entirely fair when the capacity of citizens to participate and compete in elections is constrained - indirectly - by restrictions on their civil rights. Citizens who are deprived of, say, adequate educational opportunities or the protections of the rule of law cannot be effective participants in electoral contests.

This criticism has some validity. But we take it as a caution about the fuzziness in practice between electoral and liberal democracies, rather than an objection that renders our distinction between the two regimes entirely invalid. Obviously, when discrimination in the provision of basic public goods is so extreme that it tilts the electoral playing field decisively in the direction of some groups, one cannot talk of democracy of any kind. But to require equality of access across the full range of public goods as a precondition for free and fair elections would also set too high a threshold. We treat electoral democracy as a particular kind of flawed democracy, where the majority gets to trample on the rights of the minority. We mentioned in the Introduction some of the notable examples we have in mind: Russia, Hungary, Turkey.

We now describe our taxonomy. We shall distinguish among different types of political regimes, based on the combinations of property/political/civil rights that are provided. For simplicity, let us assume that we can treat each of these rights in a binary, all-or-none fashion; they are either protected or not. This gives us eight possible combinations in all, shown in Table 1.

A regime in which none of these rights is protected is either a personal dictatorship, or an anarchy where the state has no authority (box 1 ). If property rights are protected but there are no political or civil rights, the regime is under the control of an oligarchic elite and can be described as a right-wing autocracy (box 5). A regime that provides political rights but not property or civil rights would be controlled by the effective majority, resembling perhaps Marx's dictatorship of the proletariat (box 2). A regime that provides only civil rights, on the other hand, is hard to conceptualize - the only box for which we are at a loss for label (box 3). 
Consider now political regimes that provide two out of our three sets of rights. When property rights are missing but political and civil rights are provided (box 4), we get a democratic version of communism - what Marx had in mind for the long run (even though communist regimes turned out quite differently in practice). When political rights are missing but property and civil rights are protected (box 7), we have what we might call a "liberal autocracy." Until the extension of the franchise to most males in the late $19^{\text {th }}$ century, Britain stood as an example of this type of regime. Singapore is perhaps a contemporary variant. When civil rights are missing but property and political rights are protected, we have electoral or illiberal democracies. As we argued in the introduction, the majority of today's democracies, particularly in the developing world, are in this category. Finally, a political regime that provides all three sets of rights is a liberal democracy (box 8). Our focus on the reminder of the paper is on the circumstances that permit the emergence of this kind of regime, as distinct from electoral democracies.

We shall also distinguish between three groups in society, associated with each set of rights:

1. A propertied elite, whose primary objective is to keep and accumulate their assets (property rights);

2. A majority, who want electoral power so they can choose policies that improve their economic conditions (political rights);

3. A minority (ethnic, linguistic, regional, ideological), who desire equality under the law and the right not to be discriminated against in jobs, education, etc. (civil rights).

We shall be more specific about the utility functions of each of these groups below.

The presence of these groups is a consequence of two kinds of cleavages in society. One cleavage separates the wealthy (propertied) elite from the non-elite. This is essentially an economic or class divide. The second cleavage separates the majority from the minority on the basis of some salient identity marker. This marker may relate to ethnicity, religion, language, region, or ideology. Obviously, there may be more than one such cleavage. But we shall focus on a single identity cleavage, distinct from class/income, to keep things tractable. We will call these two the class and identity cleavages, for short.

What we shall show is that (a) the depth of these cleavages and (b) the magnitude of relative numbers on either side have a direct bearing on the sustainability of different types of political regimes.

\section{A Formal Framework}




\section{(a) The basics}

We label the three groups in society with the subscript $i$, with $i$ taking one of the three possible values $e$ (elite), $a$ (majority), and $b$ (minority). Members of each group derive utility from their (after-tax) income $y_{i}$ and from consuming a public good $\pi_{i}$.

$$
u_{i}=y_{i}+\pi_{i} \text {. }
$$

We normalize the economy's total output and population to 1 , with the pre-tax/transfer shares of the elite and non-elite given by $\alpha$ and $(1-\alpha)$, respectively. We assume the elite constitute a negligible share of the population but control more than half of pre-tax/transfer output $\left(\alpha>\frac{1}{2}\right.$ ). In the absence of any taxes or transfers, $y_{e}=\alpha$ and $y_{a}=y_{b}=(1-\alpha)$. The non-elite are split between a majority and a minority, with population shares $n$ and $(1-n)$, respectively $\left(n>\frac{1}{2}\right)$. The gap between $\alpha$ and $\frac{1}{2}$ is a measure of the class (income) cleavage.

We model the identity cleavage by assuming groups exhibit differences in the type of public good they prefer. The type of public goods is indexed by $\theta \in[0,1]$. The three groups' ideal types are given by $\theta_{i}, i \in[e, a, b]$. The utility derived from the public good thus depends both on the aggregate expenditure on it and on the type of public good that is provided.

There is a deadweight loss that is associated with the provision of public goods, which increases with the level of expenditures and the gap (from the perspective of each group) between the type that is provided and the preferred type. Denoting total expenditure on the public good by $r$, the utility derived from the public good is thus expressed as follows:

$$
\pi_{i}=r-\left\{1+\left|\theta_{i}-\theta\right|\right\} \frac{\gamma}{2} r^{2},
$$

where $\gamma$ parameterizes the magnitude of the deadweight loss relative to the direct benefits associated with public goods provision. Note that deadweight loss is minimized, but not eliminated, when $\theta=\theta_{i}$. We shall normalize the majority's preferred public good by taking $\theta_{a}=1$.

A political regime allocates power across the three groups and defines the institutional constraints on policy. In particular, the political regime in place the determines (i) how the public good is financed (whether through general taxation or the extraction of a surplus from the non-elite), (ii) the level of expenditures on the public good, and (iii) the type of public good provided. This specification provides us with a parsimonious framework to distinguish between different kinds of democracies and non-democracies.

In a right-wing autocracy, political power rests with the elite who make all these decisions: they can extract resources from the non-elite (while avoiding being taxed) and they 
can set the level and type of spending on public goods to maximize their utility. In a liberal autocracy, the elite remain in the driving seat, but they cannot discriminate against any particular group either in terms of taxation or the nature of public good provided. In an electoral democracy, it is the majority's prerogative to select an economy-wide tax rate. And the majority can also choose the type of public good, disregarding the minority's wishes completely. In a liberal democracy, the majority retains control over the tax rate, but they cannot discriminate against the minority. Accordingly, they provide a public good which lies somewhere in between the majority and minority's ideal types. Other details about the political regimes will be provided below.

It bears emphasizing that we formalize civil rights, or the liberal element in liberal democracy, in a particular way. We take protection of civil rights to correspond to equal treatment in the provision of the public good. The public good in this context can be interpreted quite broadly. It could refer to health, education, and public security, as well as the administration of justice. There are other elements of civil rights, such as free speech and freedom of assembly, which may not fit comfortably under this definition. We do not claim that our treatment is exhaustive. Just as the median voter theorem fails to capture certain aspects of electoral democracy, our notion of equal-provision of public goods may miss aspects of liberal democracy. Our only claim is that we are capturing an essential element.

The analysis proceeds in two steps. First, we shall derive the different groups' payoffs associated with the political regimes in Table 1, conditional on each regime being the one in place. Next, we will discuss the equilibrium selection of political regimes - that is, how society ends up in or the other of the regimes.

\section{(b) The payoffs}

To avoid a tedious exposition, we focus in detail only on regimes in which property rights are protected. We shall discuss the outcomes in the absence of property rights briefly at the end of the section. The mathematical results for the payoffs are summarized in Table 2.

Consider first the right-wing autocracy case (box 5 in Table 1). This is the regime in which property rights are the only rights protected. We assume the elites can extract a share $\sigma$ of the non-elites' pre-transfer income $(1-\alpha)$, for a total expenditure on public goods of $r=\sigma(1-\alpha)$. They can also select their preferred type of public good, $\theta=\theta_{e}$. The rate of 
extraction $\sigma$ is determined by maximizing the elite's utility function $u_{e}^{R A}=\alpha+\sigma(1-\alpha)-$ $\frac{\gamma}{2}(\sigma(1-\alpha))^{2}$ (where RA stands for "right-wing autocracy"). ${ }^{7}$ This yields

$$
\sigma^{R A}=\frac{1}{\gamma(1-\alpha)}
$$

Substituting this expression back in $u_{e}^{R A}$ gives us

$$
u_{e}^{R A}=\alpha+\frac{1}{2 \gamma} .
$$

The non-elites are excluded from public goods in this political regime. It is only their income that is affected, which is reduced by the amount extracted by the elites:

$$
u_{a}^{R A}=u_{b}^{R A}=(1-\alpha)-\frac{1}{\gamma}
$$

Move next to the electoral democracy case (box 6). The level and type of public-goods provision are now chosen by the majority. Civil rights are not protected, which we model as the majority being free to select public goods targeted solely at their preferences $\left(\theta=\theta_{a}=1\right)$. The minority can be discriminated against by disregarding their public-goods preferences. To finance the expenditure on public goods, the majority in turn set an economy-wide tax rate $(\tau)$ by maximizing their utility $u_{a}^{E D}=(1-\alpha)(1-\tau)+\tau-\frac{\gamma}{2} \tau^{2}$. This yields:

$$
\tau^{E D}=\frac{\alpha}{\gamma}
$$

Substituting this back to $u_{a}^{E D}$, we get the equilibrium payoff for the majority

$$
u_{a}^{E D}=(1-\alpha)+\frac{1}{2 \gamma} \alpha^{2}
$$

which is clearly larger than in the $R A$ regime (eq. [5]).

The payoffs for the other two groups (the elite and the minority) can be solved by substituting (6) into their respective utility functions. This yields the following results:

$$
\begin{aligned}
& u_{e}^{E D}=\alpha-(2 \alpha-1) \frac{\alpha}{\gamma}+\frac{\theta_{e}}{2 \gamma} \alpha^{2} \\
& u_{b}^{E D}=(1-\alpha)+\frac{\theta_{b}}{2 \gamma} \alpha^{2}
\end{aligned}
$$

\footnotetext{
${ }^{7}$ We note a sleight of hand that simplifies our exposition. Technically, we need to specify the mass of elite and divide total elite income $\alpha$ by that mass. It is convenient for expositional purposes to assume this mass is arbitrarily close to unity, though the median voter remains a member of the non-elite.
} 
We note a couple of things about this equilibrium. First as long as the minority's preferred public good differs from the majority's $\left(\theta_{b}<\theta_{a}=1\right)$, the minority end up doing worse under ED compared to the majority (compare eqs. [9] and [7]). This is the result of the majority discriminating against the minority by disregarding the latter's preferences over the type of public good. The deeper the identity cleavage, measured by $1-\theta_{b}$, the higher the cost the minority suffers in the absence of civil rights, defined in this particular way.

Second, the elite suffer two distinct costs in the ED equilibrium relative to $R A$. They now both pay net taxes and consume fewer public goods. The first of these effects is captured with the middle term in eq. (8). (Recall that $\alpha>\frac{1}{2}$.) The second effect can be observed by comparing the public-goods terms in eq. (8) and (4).

We now turn to the liberal democracy case $(L D$, box 8$)$. In this equilibrium, the majority can still choose $\tau$ freely to maximize their utility, but they cannot discriminate in public-goods provision. We assume that the type of public-good provided lies somewhere between the ideal types of the majority and minority: $\theta=\bar{\theta}$, with $\theta_{b}<\bar{\theta}<1$. For example, $\bar{\theta}$ might be a population-weighted average of the two groups' preferences $\left(\bar{\theta}=n+(1-n) \theta_{b}\right)$. Setting $\theta=\bar{\theta}$, the expression for the majority's utility in this case is given by $u_{a}^{L D}=(1-\alpha)(1-\tau)+$ $\tau-\frac{\gamma}{2} \tau^{2}(2-\bar{\theta})$. The tax rate that maximizes this is:

$$
\tau^{L D}=\frac{\alpha}{\gamma(2-\bar{\theta})}
$$

Note that $\tau^{L D}<\tau^{E D}$ since the majority now derives fewer benefits from expenditures on public goods, which, in a liberal democracy, they have to share with the minority (cf. eq. [6]).

Plugging (10) in the utility functions of the three groups, we then derive the equilibrium levels of utility of the three groups:

$$
\begin{aligned}
& u_{e}^{L D}=\alpha-\frac{(2 \alpha-1)}{(2-\bar{\theta})} \frac{\alpha}{\gamma}+\frac{3-2 \bar{\theta}-\left|\theta_{e}-\bar{\theta}\right|}{2 \gamma(2-\bar{\theta})^{2}} \alpha^{2} \\
& u_{a}^{L D}=(1-\alpha)+\frac{1}{2 \gamma(2-\bar{\theta})} \alpha^{2} \\
& u_{b}^{L D}=(1-\alpha)+\left\{\frac{3-3 \bar{\theta}+\theta_{b}}{2-\bar{\theta}}\right\} \frac{1}{2 \gamma(2-\bar{\theta})} \alpha^{2}
\end{aligned}
$$

These expressions look complicated, but they have straightforward interpretations. First, note that the majority are worse off in the $L D$ equilibrium compared to the $E D$ equilibrium (compare eqs. [12] and [7)). This is a direct implication of the provision of civil rights to (or sharing of public goods with) the minority in the former case. The presence of a minority reduces the 
gains to the majority from taxing the elite in $L D$. To that extent it ameliorates class conflict. ${ }^{8}$ Second, it can be checked that the minority are better off in the $L D$ equilibrium compared to $E D$, for the same reason (eq. [13] versus [9]). The greater the identity cleavage between the majority and the minority $\left(1-\theta_{b}\right)$, the larger are both of these effects.

As for the elite, the movement from electoral to liberal democracy generates two distinct effects. First, there is a beneficial effect from the reduction in the taxes they have to pay. To see this, compare the middle terms in eq. (11) and (8), remembering that $\bar{\theta}<1$. Second, there is an ambiguous effect arising from the change in the type of public good that is provided (captured by the last terms in eqs. [11] and [8]). If the elites share an identity with the minority, the second effect becomes an unambiguous benefit as well. We can say more about the relative magnitudes of $u_{e}^{L D}$ and $u_{e}^{E D}$ by considering two polar opposite cases.

(i) Elites share identity with the majority $\left(\theta_{e}=1\right)$. In this case, the comparison between $u_{e}^{L D}$ and $u_{e}^{E D}$ depends on how large the class cleavage is. For relatively mild levels of inequality $\left(\frac{1}{2}<\alpha<\frac{2}{3}\right), u_{e}^{L D}<u_{e}^{E D}$ and elites prefer electoral democracy. When the income/class gap is bigger, $u_{e}^{L D}>u_{e}^{E D}$ and elites prefer liberal democracy. The intuition is as follows. When inequality is mild, the elite get taxed relatively little, and the fact that they get their preferred variety of public good in $E D$ makes up for the higher tax rate under $L D$. When inequality is high, on the other hand, it is the tax rate that matters more, and the elite would rather have the lower taxes in $L D$, even if that means a more poorly targeted public good.

(ii) Elites share identity with the minority $\left(\theta_{e} \ll 1\right)$. Consider an extreme version of this scenario where $\theta_{e}=0$. In this case, elites would get no public goods under $E D$ at all, so they unambiguously prefer $L D$ to $E D$. And this is true regardless of the depth of the class cleavage. More generally, the closer the elite and minority identities are aligned and the deeper the identity cleavage, the more likely that the elites prefer $L D$ to $E D$.

So far we have discussed three out of the four regimes in which property rights are protected. The remaining possibility is the combination of property rights with civil rights, a regime that we called "liberal autocracy" $(L A)$. In this case, we assume elites are the ones that set the tax/extraction rate (as in $R A$ ), but they do not exclude non-elites from the benefits of the public good and they tax themselves as the rest of society. The equilibrium tax rate, denoted $t$, is

$$
t^{L A}=\frac{1-\alpha}{\gamma}
$$

\footnotetext{
${ }^{8}$ There is some literature that discusses how identity cleavages may soften class-based politics: voters who view themselves as members of a particular, say, ethnic group may vote alongside other members of the group, many of whom may also be rich. See Roemer (1998), Shayo (2009), and Huber (2014). In our framework, the causal channel is different, and operates through diminished incentives for public-goods provision.
} 
which is smaller than the extraction rate under right-wing autocracy ( $R A$, see eq. [6]). This tax rate is also smaller than the outcome under $E D$ (see eq. [6], recalling that $\alpha>\frac{1}{2}$ ). The associated utility levels for the three groups are

$$
\begin{gathered}
u_{e}^{L A}=\alpha+\frac{(1-\alpha)^{2}}{2 \gamma} \\
u_{a}^{L A}=(1-\alpha)+\left\{(3 \alpha-1)-\left|1-\theta_{e}\right|(1-\alpha)\right\} \frac{1-\alpha}{2 \gamma} \\
u_{b}^{L A}=(1-\alpha)+\left\{(3 \alpha-1)-\left|\theta_{b}-\theta_{e}\right|(1-\alpha)\right\} \frac{1-\alpha}{2 \gamma} .
\end{gathered}
$$

The non-elites prefer $L A$ to $R A$ since they get some public goods in the first case. But from the perspective of the majority $E D$ dominates both, since it is the majority that sets the tax rate under $E D$. The best possible outcome for the majority under $L A$ occurs in the limit case when the elites and the majority have the same identity $\left(\theta_{e}=1\right)$ and there is perfect equality $\left(\alpha=\frac{1}{2}\right)$. In that case, it can be checked that the majority do equally well under $E D$ and $L A$. But under all other circumstances, $u_{a}^{E D}>u_{a}^{L A}$. The gains to the majority from moving from $L A$ to $E D$ are increasing in the wealth and identity gaps.

Unlike the majority, the minority can be better off under $L A$ compared to $E D$. This is because the minority do not do that well with the public good when the majority selects its type and discriminates against the minority. When the identity cleavage runs deep, this raises the possibility that the elite may coopt the minority against the majority and forestall the emergence of democracy $(E D)$ by offering $L A$ instead.

To complete the description of the various political regimes, we need to specify also what happens when property rights are not protected (boxes 1-4). For purposes of the discussion that follows, we do not need to describe each one of these cases separately. We just need to say something about the payoffs in case the non-elite succeed in expropriating the elite. For concreteness, let us call this the dictatorship of the proletariat case $(D P)$. We assume a portion $\varphi$ of the economy's productive capacity is destroyed or becomes useless in the process. Elites' utility is driven to zero, while utility levels for the non-elite depend crucially on the deadweight loss parameter $\varphi$ :

$$
\begin{aligned}
& u_{e}^{D P}=0 \\
& u_{a}^{D P}=1-\varphi \\
& u_{b}^{D P}=1-\varphi .
\end{aligned}
$$


We now have all the detail we need to compare payoffs across different types of regimes. Where we end up in equilibrium, however, will also depend on the likelihood that non-elites can successfully expropriate the elite and the nature of the game being played among the groups. We discuss these in the next section.

\section{$\underline{\text { IV. Determination of Political Regimes }}$}

In this section we examine political transitions from a right-wing autocracy. We are interested in analyzing whether electoral democracies are more likely to emerge than liberal democracies, and the conditions that help push the transition in one direction or the other. We begin by recognizing that our analysis may be affected by the details of how we specify the game between the various players (e.g. the nature of bargaining, coalition formation and sidepayments). Accordingly, in subsection (a) we impose only a minimal structure to analyze the set of feasible political transitions. We demonstrate that under reasonable conditions, the parameter space that yields liberal democracy is narrower than that which generates electoral democracy. In subsection (b) we use a specific game structure to examine political transition under a benchmark set of parameters.

We should state at the outset that our focus is on the constellation of interests that make different regimes possible, rather than on questions of credibility or commitment. Loosely speaking, we assume that any political regime that is feasible ex ante is sustainable ex post - either through repeated game incentives operating in the background or through institution-building that makes departures from political settlements costly. This is not to belittle the importance of credibility and enforcement problems in political agreements. However, these problems are rather transparent in our case, and not much is gained by explicitly formalizing them. In particular, we conjecture that the effect of credibility problems is to undercut liberal democracy further. The majority and the elite always have more power to rewrite the rules ex post. We push such issues aside to examine the set of constitutive agreements that are interest-compatible (even if not always dynamically consistent).

\section{(a) Political transitions to democracy: the feasible set}

The status-quo regime is right-wing autocracy $(R A)$ in which elites have property rights and control the polity. The transition is triggered by structural changes in the economy or technological (or other) shocks that make it easier for the majority (either alone or in coalition with a minority) to threaten a revolution against the elite's hold on power. We distinguish between two scenarios. The first is the case where the elite faces a credible threat of revolution from the majority group alone (either because the minority is politically "passive" or too small 
to matter). In the second case a successful revolution requires participation by both the majority and the minority.

In order to systematically analyze these two cases separately we make the following assumptions. The number of participants in the revolution must exceed the threshold level $n^{*} \leq 1$ before a revolution can be launched. We further assume that $(1-n)<n^{*}$, so that the minority can never mount a revolution on their own. Once initiated, a revolution has a fixed probability $\rho$ of success. If the revolution is successful, the elites are expropriated and the payoffs are as shown in eqs. (18)-(20). If the revolution is unsuccessful, the majority obtains a utility of 0 (and the elite continue to reap $u_{e}^{R A}$ ). Note that the status quo regime $R A$ is the only equilibrium outcome when the expected payoff from a successful revolution are sufficiently low. The necessary condition for any other regime to emerge in equilibrium is:

$$
\rho u_{a}^{D P}>u_{a}^{R A} .
$$

Substituting from (5) and (19), this requires $\rho(1-\varphi)>(1-\alpha)-\frac{1}{\gamma}$. When this inequality is violated, non-elites can never credibly threaten to revolt as their expected utility would be reduced relative to the status quo. Higher inequality (i.e., larger $\alpha$ ) as well as a lower deadweight $\operatorname{cost} \varphi$ (e.g. organizational cost of revolution) will make revolution more likely. This suggests that the elite is more likely to be willing to abandon $R A$ in favor of an alternative regime, when the class/income cleavage is higher.

Consider now the possibilities when equation (21) is satisfied and there is a real prospect of a political transition away from the right wing autocratic status quo. We are interested in examining the circumstances under which liberal democracy emerges when the minority is politically irrelevant for the revolution (i.e., $n \geq n^{*}$ ) and when it is not (i.e. $n<n^{*}$ ). We consider each of these two cases in turn.

(i) $n \geq n^{*}$

In this case the minority do not have any strategic importance as a driver of political change. It is only the preferences of the elite and majority that count towards any negotiated settlement. As suggested earlier, the specific outcomes of any settlement will naturally depend on the particulars of the game that is laid out. We can, however, say something about equilibrium regime formation by ruling out the emergence of political institutions that violate participation constraints or are clearly dominated for both the majority and the elite.

First, the equilibrium regime must yield utilities that are not below the elites' and majority's reservation level of utilities. In other words, in any negotiated political transition the participation constraint for both the elite and the majority should be met. Denoting equilibrium utility with an asterisk, the majority's participation constraint is simply: 


$$
u_{a}^{*} \geq \rho u_{a}^{D P}
$$

Secondly, we define a Pareto domination criterion in regime selection. In particular, we assume that a political regime will not emerge in any reasonable equilibrium if there is an alternative regime that is preferred by both the majority and the elite. Such a regime will be Pareto-inferior from the perspective of these two groups, who can both do better by moving to the alternative. We can now state:

Proposition 1. When $n \geq n^{*}$, and under the assumption that any negotiated political transition satisfies the two restrictions just stated, there exist parameter combinations under which ED will emerge and $L D$ will not. The reverse is not true.

This proposition formalizes the intuition that $L D$ has more demanding prerequisites than $E D$. Both the participation constraint and the Pareto-domination criterion suggest that electoral democracy is more likely than liberal democracy to emerge in any negotiated political transition.

Consider first the majority group's participation constraint expressed by eq. (22). Since the majority always prefers $E D$ to $L D$, the condition is satisfied more easily for $E D$ than it is for $L D$. In particular, there are parameter combinations such that

$$
u_{a}^{E D}>\rho u_{a}^{D P}>u_{a}^{L D}
$$

When these inequalities hold, the majority would reject revolution when it is offered $E D$ but not when it is offered $L D$. However, it is not possible for the majority's reservation utility to be bracketed by $u_{a}^{E D}$ and $u_{a}^{L D}$ in the opposite direction. So the majority would never reject $E D$ when it is willing to accept $L D$. This is the first source of the asymmetry between the two regimes.

Next consider the Pareto-domination criterion. Since ED is the majority's most preferred regime, it can never be Pareto dominated. $L D$, by contrast, is neither group's most preferred regime. Further, there are parameter combinations under which $u_{e}^{E D}>u_{e}^{L D}$ so that the elite prefers $E D$ to $L D$. This ensures that $L D$, unlike $E D$, can be Pareto dominated, and is the second source of asymmetry.

Consider the circumstances under which $E D$ is preferred by the elite to $L D\left(u_{e}^{E D}>\right.$ $u_{e}^{L D}$ ) and is therefore the Pareto-preferred regime of both the majority and the elite. There are two factors at work that shape elite preferences over this particular choice. First, they get taxed more in $E D$ than in $L D$. The importance of this effect increases as the class cleavage (measured by $\alpha$ ) grows bigger. Second, depending on their identity, they bear a benefit or a cost. When the elite share an identity with the majority $\left(\theta_{e} \approx 1\right)$, they do better in $E D$ on account of this 
effect, as they benefit, along with the majority, from discrimination against the minority in the provision of the public good. Hence, when inequality is not too high and there is no identity cleavage separating the majority from the minority, $L D$ will be strictly dominated by $E D$.

(ii) $n<n^{*}$

Now the majority needs the minority to tag along in order to induce the elite to accept a regime other than $R A$. This transforms the minority into a strategic actor, and potentially both sources of asymmetry discussed previously disappear. (The reservation utilities are now different, however, since neither of the non-elites can mount a revolutionary challenge on its own.) The specifics, again, will depend on how the game is mapped out. But we can make two broad generalizations that apply regardless of the game form.

First, the minority has some power now, and this means they are more likely to get an outcome favorable to them. However, and this is the second point, this need not guarantee democracy, liberal or otherwise. The minority is generically better off in $L D$ than in $E D$. But as we discussed previously, under some conditions they can do even better under LA compared to $E D$. The deeper the identity cleavage between majority and minority, the more likely is the latter scenario. This creates room for the minority to enter an alliance with the elite as opposed to the majority. In other words, the minority can be co-opted by the elite. This results in $L A$ rather than $L D$.

These considerations suggest that electoral democracy will emerge in a much wider set of circumstances than liberal democracy. But the precise nature of the equilibrium when the elite and the non-elite are strategic players remains unclear. Accordingly, we delineate below a simple game where all the key players act strategically and examine the political regimes that arise in equilibrium.

(b) Political transitions and regime selection: An equilibrium analysis

In most respects, we retain the structure described above. We continue to assume that at the beginning of the first period the $R A$ regime is no longer viable, i.e. $\rho u_{a}^{D P}\left(=\rho u_{b}^{D P}\right)>$ $u_{a}^{R A}\left(=u_{b}^{R A}\right)$. On observing the prospect of revolution, the elite move first and offer a regime in the set $\{L A, E D, L D\}$. The majority move next, and they either accept the regime offered, or they mount a revolution. Finally, the minority move last, and they decide either to join the revolution or to stay put.

Remember that $u_{e}^{D P}=0$ (eq. [18]). Therefore, as long as at least one of the three regimes $\{L A, E D, L D\}$ yield utility to the elite that exceeds $(1-\rho) u_{e}^{R A}$, the elite always prefer 
to stave off revolution by introducing a new political regime. Whether they can successfully do so, however depends, on whether the majority can reap a utility that exceeds its reservation utility under an attempted revolution, $\rho u_{a}^{D P}$. If such a regime exists, there will not be a revolution attempt on the equilibrium path of the game. Otherwise, the elite cannot prevent a revolution, and with probability $\rho$ the equilibrium ends up in $D P$.

We work with a specific set of parameters to examine how the equilibrium depends on the interaction of the income/class cleavage, $\alpha$, with the identity cleavage. We assume that the elite share an identity marker with the majority $\left(\theta_{e}=1\right)$, while the majority-minority identity cleavage is large $\left(\theta_{b}=0\right)$. We set the type of public good under $L D$ in the mid-point of the range $(\bar{\theta}=0.5)$. Finally, $\gamma=2, \varphi=0.3$ and $\rho=0.5$. This is a useful benchmark that simplifies the characterization of possible equilibria, as we shall see. Other parameter combinations are obviously feasible and would produce different equilibrium configurations. The intuitions behind other possibilities is easy to develop once we work through this particular case.

Figures (2)-(4) show how the utilities of the three groups vary with $\alpha$ under the selected parameters. We shall use these figures to examine the equilibria for different ranges of the income/class cleavage. As usual, we work backwards, considering the minority's decision first. We distinguish again between the two cases $n \geq n^{*}$ and $n<n^{*}$.

(i) $n \geq n^{*}$

In this case the majority have the numbers to mount a revolution and the minority's decision is of no consequence. Neither the elite's nor the majority's actions in prior stages is affected by what the minority does. (Remember that $(1-n)<n^{*}$.) So the equilibrium outcome is invariant to what happens at this last stage.

Moving back one stage, the majority will accept any regime that yields utility higher than its expected utility when it attempts a revolution, $\rho u_{a}^{D P}=\rho(1-\varphi)$. This reservation level of utility is shown in Figure 2 by the flat line. When $\alpha$ is beyond a threshold $\alpha_{a}^{\max }$ (around 0.8 in our example), there is no such regime and the game will end in a revolution attempt. In other words, when the income/class cleavage is sufficiently deep, even if the elite were to offer $E D$, this would not satisfy the majority's participation constraint and the majority would be better off trying to mount a revolution.

As we can see from Figure 2, there is a minimum threshold $\alpha_{a}^{\text {min }}$ below which the majority will accept any of the offers in the set $\{L A, E D, L D\}$. Between $\alpha_{a}^{\min }$ and $\alpha_{a}^{\max }$, there is also an intermediate threshold $\alpha_{a}^{i n t}$ which defines the following two additional zones: between $\alpha_{a}^{\text {min }}$ and $\alpha_{a}^{i n t}$, the majority is willing to accept either $L D$ or $E D$, but not $L A$; and between $\alpha_{a}^{i n t}$ and $\alpha_{a}^{\max }$, the majority is willing to accept only ED. 
In the first stage of the game the elite will offer the regime that yields it the greatest utility, given the choices of the majority described above. Note from Figure 4 that the elite always (at least weakly) prefer $L A$ to the other two regimes. The ranking of $E D$ and $L D$ in turn depends on whether $\alpha$ is larger or smaller than the critical level $\alpha_{e}^{*}$. When $\alpha<\alpha_{e}^{*}$, the elite prefer $E D$ to $L D$. When $\alpha>\alpha_{e}^{*}$, the elite's preference switches to $L D$. We note also that $\alpha_{e}^{*}<$ $\alpha_{a}^{\min }$ (cf. Figs. 2 and 4).

We can now state the equilibrium of the game.

Proposition 2. Under the sequence of moves described above and the parameter assumptions stated, the equilibrium configuration of the political regimes is as follows:

(i) when $\alpha \leq \alpha_{a}^{\min }$, the elite offer LA and the majority accepts it;

(ii) when $\alpha_{a}^{\min }<\alpha \leq \alpha_{a}^{\text {int }}$, the elite offer $L D$ and the majority accepts it;

(ii) when $\alpha_{a}^{\text {int }}<\alpha \leq \alpha_{a}^{\max }$, the elite offer ED and the majority accepts it;

(iv) when $\alpha>\alpha_{a}^{\max }$, the majority mount a revolution regardless of what the elite offer.

Notice that when the income/class cleavage is large (but not so large as to induce the majority to revolt), we get $E D$ as the equilibrium outcome rather than $L D$ (zone (iii)). This is so even though the elite prefer $L D$ to $E D$ for larger $\alpha\left(>\alpha_{e}^{*}\right)$. In this zone, it is the participation constraint of the majority that binds, and it is their preferences that dictate the outcome. For low $\alpha$, on the other hand, the elite can get away with $L A$, and do not need to offer $L D$.

Hence, the proposition highlights an interesting implication of our analysis. It shows that the region in which $L D$ emerges as an equilibrium is squeezed from below by the availability of $L A$ (which satisfies the elite's incentive constraint) and from above by ED (which satisfies the majority's participation constraint).

We note further that the $L D$ zone is smaller or larger depending on the nature of identity cleavages. Two cases are particularly relevant, in light of our discussion in the next section. First, when the elite share an identity with the minority they would prefer $L D$ to $E D$ for a larger share of the parameter space. In Figure $4, \alpha_{e}^{*}$ moves to the left (becomes smaller) as $\theta_{e}$ gets closer to 0 . If, for whatever reason, $L A$ is ruled out, this makes $L D$ an equilibrium for lower levels of $\alpha$ than in our benchmark case. Second, when the identity cleavage between majority and minority gets smaller, the majority's preference for $E D$ over $L D$ becomes weaker. In Figure 2, the $L D$ schedule moves closer to the $E D$ schedule, expanding the zone in which $L D$ is the equilibrium, and shrinking the zone in which $E D$ emerges. In the limit, when $\theta_{a}=\theta_{b}=1$ (no identity difference among the non-elite), the two schedules overlap completely. Both of these 
cases render $L D$ more likely. We do not develop these cases in detail, but we will refer to them when we discuss the historical and country evidence in the next section.

(ii) $n<n^{*}$

Working backwards again, the minority can now make a difference by joining the revolution, if the majority have launched one. They will do so if and only if they are not offered a regime that improves their utility compared to the expected utility they get under an attempted revolution. And in the previous stage, the majority will launch a revolution only when they know the minority will subsequently join them.

From the perspective of the elite, in the first stage of the game, the constraints are now looser than in the previous case with $n \geq n^{*}$. That is because the threat of revolution can be thwarted by offering enough to either the majority or the minority. So the elite will do at least as well here as in the previous case.

Despite these differences, under the parameters we selected - and in particular the assumptions that $\theta_{b}=0$ and $\bar{\theta}=0.5$ - it turns out that the equilibrium is unaffected when the size of the majority falls short of the minimum threshold required for revolution. This is mainly because $L D$ and $L A$ yield identical payoffs to the majority and minority, eliminating the advantage that the elites would have in general by being able to split the "coalition." We briefly discuss the details.

Revolution now requires that it be the dominant strategy for both the majority and minority. The range of $\alpha$ for which this is true is given by $\alpha>\max \left[\alpha_{\mathrm{a}}^{\max }, \alpha_{b}^{\max }\right]$. In other words, in general the elite can avoid revolution for a broader range of income/class cleavages. Under our parameters, $\alpha_{\mathrm{a}}^{\max }>\alpha_{b}^{\max }$, so the operative limit remains the majority's upper threshold.

At the lower end of the range for $\alpha$, there is scope for the elite to co-opt the minority by offering $L A$, as we discussed earlier. As can be seen from Figure 3, for $\alpha \leq \alpha_{b}^{\text {int }}$, this strategy works and prevents the minority from teaming up with the majority. Since liberal autocracy produces identical payoffs to the minority and majority under our parameters, we have $\alpha_{b}^{i n t}=$ $\alpha_{a}^{\min }$, and the boundary for $L A$ remains unchanged as well.

Consider next what happens when $\alpha_{b}^{i n t}<\alpha \leq \alpha_{a}^{\max }$. Note first that $\alpha_{b}^{\text {max }}=\alpha_{a}^{\text {int }}$, as both of these refer to utilities under $L D$ where the outcomes are identical for the majority and minority under our parameters. With this in mind, there are two zones in this interval: (i) $\alpha_{b}^{\text {int }}<\alpha \leq \alpha_{b}^{\max }=\alpha_{a}^{i n t}$, and (ii) $\alpha_{b}^{\max }=\alpha_{a}^{i n t}<\alpha \leq \alpha_{a}^{\max }$. In the first of these, the majority prefers both $E D$ and $L D$ to revolution, while the minority prefers only $L D$ to revolution. In the second, the majority prefers $E D$ to revolution, while the minority strictly prefers revolution. The elites will then offer $L D$ in the first zone and $E D$ in the second. 
Hence the equilibrium configuration of the regimes is identical to the previous case, and is as stated in Proposition 2.

\section{$\underline{\text { V. Historical discussion and country cases }}$}

We now provide some historical context and a few country vignettes to illustrate and enrich our conceptual framework.

It has become common to treat "liberal democracy" as a single political package. But its two ingredients have different origins, social bases, and political implications (Plattner 2010, Fukuyama 2014). As a system of thought, liberalism grew out of the Protestant reformation and the religious wars that followed. ${ }^{9}$ It emphasized opposition to religious monopoly, tolerance, and equal treatment by the state regardless of religious beliefs (Ryan 2012, p. 7). Its first important political victory was the Glorious Revolution of 1688 in England, in which the landed gentry succeeded to place limits on the power of the sovereign, with the subsequent Bill of Rights (1689) codifying those restraints. John Locke (1632-1704), who lived through the Glorious Revolution, is considered the first important theorist of liberalism. Classical liberalism reached its apogee with John Stuart Mill's (1806-1873) book On Liberty, published in 1859.

While democracy has roots in ancient Greece, its modern variant emerged out of the social mobilization sparked by the Industrial Revolution in Britain and other parts of Western Europe. As farmers moved to the cities and were transformed into factory workers, the possibilities of mass collective action increased and organized labor became a political force. The push for democracy during the $19^{\text {th }}$ century was essentially a demand for the expansion of the franchise to the non-propertied. This was a struggle that took a century or longer, with universal suffrage achieved in Western Europe and its offshoots by the early to mid-twentieth century. The role that industrialization - and the associated emergence of the bourgeoisie and proletariat - played as the instigator of modern democracy is a common theme running through accounts of democracy, from Barrington Moore's (1966) classic work to more recent analyses of democratic transitions in Latin America and Southern Europe (Collier and Mahoney 1997).

As this capsule history suggests, liberalism preceded electoral democracy in the West. Early liberals were propertied elites, landed gentry, and wealthy taxpayers whose primary objective was to prevent the crown from exercising arbitrary power over them. It was the rule of law they were after -- not the sharing of power with the masses. Indeed, classical theorists of

\footnotetext{
${ }^{9}$ There is a question as to whether liberalism is a specifically Western invention. Sen (1999) argues that the ideas of religious tolerance and acceptance of diversity are ingrained in non-Western cultures as well.
} 
liberalism were quite nervous about expanding the franchise and worried about its consequences. Government was too important to be left to common people, whose judgment was fickle and untrustworthy. And contemporary developments seemed to justify their fears. In France, the extension of the vote to all males in 1848 enabled Louis Napoleon to woo the peasantry and paved the way for his personal dictatorship. Alexis de Tocqueville had written disparagingly about the "tyranny of the majority" in the United States. Mill picked up on de Tocqueville's discussion and argued that the principles he enunciated in On Liberty "did not apply to people who could not benefit from rational discussion" (Ryan 2012, p. 29). Among such people were the population of $16^{\text {th }}$ century Britain, $18^{\text {th }}$ century Russia, and of course the Indians of his day (over whom Mill took a hand in ruling as an official of the East India Company).

The fact that early liberals in the West were in large part the wealthy property-owning elite led to the bundling, in the minds of subsequent analysts, of two kinds of distinct rights: property rights and civil rights. The opponents of absolutism by the crown and the church were after both sets of rights. This peculiar, and peculiarly British, history does not fit the experience of other, especially non-Western countries very well. In particular, the elite would often turn out to be interested primarily in property rights. Civil rights were for others, chiefly ethnic, religious, or other minorities.

This conflation of property and civil rights can be seen in T.H. Marshall's (1949) classic account of the historical development of rights. Marshall divides rights into three categories: he argues civil rights came first, followed by political, and then social rights. His political rights category aligns with ours as it refers largely to rights deriving from the franchise. His social rights refer to benefits provided by the state under welfare state arrangements. His civil rights, meanwhile, encompass both our property and civil rights. For Marshall, protection of property rights was one of the rights necessary for individual freedom; it was of the same nature as the protection of free speech, non-discrimination on the basis religion, and the right to justice. It is clear that Britain's history led Marshall and others to treat the pursuit of civil rights as an elite project. By the time Somers (1994) reviews Marshall's treatment nearly half a century later, property rights is so taken for granted that it has dropped out of Marshall's definition of civil rights.

When Western liberals eventually came to accept democracy, it was, as Fawcett (2014) portrays it, a grudging concession. Fawcett writes of the decades between 1880 and 1914 as the period in which liberals made peace with democracy. As part of the compromise, liberals gave their support to the expansion of the franchise. They yielded to popular sovereignty over domains such as education and ethics in which they previously had a monopoly. In return, they 
hoped that popular forces would accept "liberal limits on the authority of the people's will" (Fawcett 2014, 144). Thus was born liberal democracy.

However, one of the predictable consequences of mass franchise was that liberals proper lost power to mass based political forces. In Britain the Liberal Party experienced a dramatic decline before World War I as the Labor Party gained ground, and would henceforth be condemned to remain a third party at best. In Germany, by the 1890s the liberals were "squeezed between the world's largest, best organized labor movement and the world's largest, best organized Catholic Party" (Fawcett 2014, 170). Mass democracy in time also generated justifications for itself - such as the "national will" or the "vanguard party" of the proletariat -that departed significantly from liberal tenets (Müller 2011, p. 3). During the interwar period, economic depression greatly accelerated the decline of liberalism. Mass based political movements steeped on the highly illiberal ideologies of fascism and communism swept through continental Europe.

But liberal democracy would experience a rebirth in the West after the Second World War. Part of it was of course the discrediting of fascism and Nazism. But in countries where liberalism had preceded democracy, liberal democracy would prove remarkably resilient. The welfare states of the postwar era were based on a very different type of bargain between employers and employees - providing the latter with much expanded social rights - but they were constructed on the same elite/working-class cleavage that had instigated the $19^{\text {th }}$ century rise of democracy in the West. Some would say that these regimes had given up on liberalism in expanding the economic and social powers of the state. But judged by criteria such as the rule of law, non-discrimination, and equality in the distribution of public goods, the welfare states of Europe and North America were indeed liberal democracies.

In other, non-Western parts of the world, mass politics arrived typically as a consequence not of industrialization, but of de-colonization or wars of national liberation. It wasn't economic change and the rise of factories that spurred social mobilization, but national struggles against colonizers or foreign enemies. So the relevant cleavages were from the very beginning based on ethnicity or nationality rather than class or economic status. This was reinforced by the fact that colonizers had often codified and deepened pre-existing identity cleavages and allied themselves with some, often minority ethnicities against others in order to facilitate their rule.

The nationalist movements of the developing world more or less all claimed to be democratic in some fashion - even those who ascribed explicitly to socialist or communist ideology. But theirs was a democracy that was based largely on identity cleavages. It was explicit about the "people's" right to rule over ethnic-religious-linguistic minorities or defend 
against a presumed external enemy. It was unlikely to promote liberal practices and prone to deteriorate into electoral democracy or worse.

So if the liberal component of liberal democracy never took hold in much of the world, the reasons are probably both ideational and structural. On the ideational front, countries Asia, Africa, and Latin America lack a tradition of liberalism and liberal ideas. Unlike in the West, democracy and mass politics arrived in these countries before liberalism.

On the structural front, democratic mobilization took place along quite different cleavages. In the West, democracy arrived when the dominant cleavages were the class differences created by industrialization. As our model suggests, under those conditions the elites preferred liberal democracy (to electoral democracy), while for the majority the differential gains from electoral democracy (relative to liberal democracy) were minor. In the developing world, democracy came when the dominant cleavages were identity-based. As Fatton $(1990,457)$ puts it in the African context:

Because of its colonial legacy and its peripheral-dependent nature, African capitalism has failed to generate the development of both a hegemonic bourgeoisie and a strong proletariat - the two classes whose conflicts and confrontations are critical in striking the political compromises and bargains necessary to the establishment of liberal democracy. The absence of these confrontations and conflicts has prevented the growth of liberalism with its ideological and legal emphasis on individual rights, civil liberties, and freedom of association.

In those circumstances, groups that control political power had a strong incentive to pursue illiberal policies that discriminate against minorities. Another, more recent trend that weakens the prospects for liberal democracy in the developing world is the onset of premature deindustrialization, as documented in Rodrik (2015).

Against this baseline set of predictions, it is useful to consider some specific counterexamples of liberal democracy in the developing world. Their particular circumstances help underscore the importance of the enabling factors that we have emphasized in the paper.

South Korea. After a brief and troubled experience as a democracy in the 1950s, South Korea was ruled with a firm hand by military dictators throughout the 1960s, 1970, and much of the 1980s. The early to mid-1980s was a period of increasing repression of opposition groups. It was a broad coalition of workers and students that agitated for and eventually obtained democratic elections against that background. A group of labor unions had created a democracy alliance in 1984, and they were subsequently joined by student groups, opposition politicians, and even religious leaders across the spectrum. The democratic transition occurred in 1987, following mass rallies and demonstrations by workers and students. 
It is not uncommon for governments to be brought down by mass demonstrations. What is striking is that in the Korean case this produced a political system, which within two decades, was widely recognized as a Western-style liberal democracy. In 2015, the country ranked 25th out of 102 countries in fundamental rights according to the World Justice Project (WJP 2015, 27), ahead of the United States and just behind Chile (see Botero and Ponce 2012 on the WJP methodology). As one analyst has put it, Korea's democratic transition is as miraculous as its economic transformation (Chaibong 2008).

Korea fits rather well in our story. First, it is a country that is remarkably homogeneous in terms of language and ethnicity (if not religion). The main identity cleavage on which the authoritarian regime relied to mobilize domestic support was the military threat posed by the communist regime of North Korea. But the nationalist line lost its appeal over time as a consequence of the differential economic progress of the two halves of the Korean peninsula. Given the gains in the South and the economic decline of the North, the idea that the North posed a serious threat and should be viewed in antagonistic terms became anachronistic over time.

Second, Korea experienced significant industrialization, with more than a quarter of the labor force in manufacturing by 1987 . This is reminiscent of the Western experience in the $19^{\text {th }}$ century, where democratic mobilization took place against the background of the Industrial Revolution. The similarity is further highlighted by the fact that workers and labor unions played a leading role in the democracy movement in Korea.

In sum, we would argue that Korea's liberal democracy has much to do with the relative absence of identity cleavages and the leading role played by the labor movement in mobilizing against the military/industrial elite.

Lebanon. Lebanon may be an odd country to bring up as an example of liberal democracy in view of hard times which have befallen the country's political system. But prior to the civil war, which lasted from 1975 to 1990, it was a model democracy in a region sorely lacking in liberal politics. It could be listed, without any justification of sorts, alongside Switzerland and Austria as a liberal democracy (Lehmbruch 1967) and as a successful example of a "consociational democracy" (Lijphart 1969).

In terms of identity cleavages, Lebanon probably represents the polar opposite of South Korea. It is a mosaic of religions and ethnicities. The country is divided between Christians and Muslims, with each major religion in turn divided among different denominations (Maronite, Greek Orthodox, Shia, Sunni). It has a history of providing each religious community its own autonomy going back to the millet system under the Ottomans. The modern consociational regime was created in 1943 by a national pact between the Muslim and Christian communities. What is distinctive about this regime is that public offices are explicitly apportioned among religious denominations. At the apex of the political system the Presidency was allocated to a Christian Maronite, the Premiership to a Muslim Sunni, and the Speakership to a Muslim Shiite. This principle extended downwards to other government positions. 
As Lijphart $(1969,218)$ noted, a key feature that makes such a regime sustainable is that no single group has a majority and therefore can expect to retain power indefinitely in electoral competition (see also Dixit, Grossman, and Gul 2000 for a formal analysis). Any group that wants access to power must rely on the cooperation and goodwill of at least some of the others. Furthermore, no single group is close to having a majority either. The latter rules out the shortrun temptation of manipulating the rules for permanent advantage. The Lebanese example corresponds loosely to the case in our model where the "majority" is not strong enough to attain power and needs the "minority" to go along with it. ${ }^{10}$ Such cases are generically more conducive to liberal democracy.

The reasons behind the decline of Lebanon's democracy are also telling. The principal cause behind the civil war was the influx of Palestinian refugees from Jordan, which altered the balance between Muslims and Christians. There had not been a census since the 1930s and there was already a sense that the existing distribution of political power was short-changing the Muslims. With the influx of Palestinians, the consociational regime became unsustainable and civil war erupted. External intervention by the Israelis and Syrians, with each supporting their own client groups, was a further destabilizing factor.

Liberal democracy along consociational lines relies on a knife-edge sort of expectations - that none of the groups have the numbers or the power to prevail over the rest. It is not clear whether the Lebanese case would have lasted for long in view of the fragility of such regimes in changing environments. Large-scale demographic shocks and external intervention certainly did not help.

South Africa. In 1994, South Africa transitioned to democracy, thanks to a negotiated settlement between the African National Congress (ANC) and the white minority government. This was a landmark pact, as the elites who ran the apartheid regime had so much to lose. They had long controlled not only the instruments of power, but also the economic wealth of the country. There was a huge economic gap between the whites and the disenfranchised blacks. Expanding the franchise might have been expected to produce vastly redistributive policies, if not outright expropriation of the white minority.

In the event, South African democracy produced only moderate amounts of redistribution. The ANC government did institute measures that gave blacks a greater share of ownership of the capital stock and produced a black wealthy elite. But the economic interests of the whites were largely unaffected, an outcome that Inman and Rubinfeld (2012) attribute to the peculiar federal arrangements that were negotiated during the transition. More to the point, in the context of the present analysis, is that South Africa emerged largely as a liberal democracy. The South African polity has operated under considerable strain, and has often strayed from its liberal principles. (A recent example is the treatment of immigrant workers.)

\footnotetext{
${ }^{10}$ We have only two groups in our model, which is an artifact of having a single identity cleavage. To track the Lebanese example more closely we would have to consider multiple identity cleavages. But the logic is a straightforward extension of our majority-minority framework.
} 
Nevertheless, the country is generally considered one of two liberal democratic successes in Sub-Saharan Africa, alongside Ghana (Mattes and Gyimah-Boadi 2003). Given the history of institutionalized discrimination under apartheid and the large majority the ANC has enjoyed in parliament since 1994, this is a remarkable achievement.

The key in South Africa was that the whites were a distinct minority on the identity dimension. In terms of our model, the elites were keenly interested in protecting not just their property rights, but also their civil rights. As the distinguished South African jurist Richard Goldstone (1997) put it, "without some guarantee of protection for the rights of minorities, the previous ruling white minority government would not have relinquished power to an inevitably black-controlled majority government." The ANC, with its early focus on human rights, had in fact adopted a Freedom Charter containing elements of a bill of rights as early as 1955 . There was widespread agreement by the early 1990s that a bill of rights had to be part of the new settlement. The 1996 constitution eventually included a detailed bill of rights that enshrined civil rights in the constitution and prohibited discrimination, while leaving room for affirmative action.

The South Korean, Lebanese, and South African cases offer three different paths towards liberal democracy. They each rely on somewhat special circumstances: industrialization driven labor mobilization in a society lacking distinctive identity cleavages (South Korea since the late 1980s); multiple identity cleavages that deny any single group the hope that it could claim and cling to power on its own (Lebanon during the 1950s and 1960s); and a major identity cleavage that aligns neatly with the wealth/class cleavage, leaving the elite in dire need of both property and civil rights protection (South Africa since 1994). The South Korean pattern is the one most reminiscent of the traditional Western path to liberal democracy. The other two rely on particular identity cleavage configurations. It could be surmised that they are generically more fragile as a result.

\section{$\underline{\text { Vl. Concluding remarks }}$}

Our focus in this paper has been on the constitutive bargains that lie at the origin of different political regimes, liberal democracy in particular. It goes without saying that such bargains can obsolesce over time. Class and identity cleavages evolve as a result of exogenous developments in the economy and society as well as political strategies pursued by groups contending for power. Commitments made during negotiated pacts and written into law and enshrined in institutions may prove unsustainable, when one of the groups - the elite or the majority - perceives clear gains from rewriting the rules through opportunistic behavior. Problems of self-enforcement are endemic in political systems.

The emergence of liberalism has been discussed to date mostly in the realm of the history of ideas. The political economy literature on democratic transitions, meanwhile, has largely conflated electoral democracy with liberal democracy. Our aim in this paper was to 
partially fill in the blind spots that were created as a result. We have stressed that liberal democracy is a special beast. It does not arise if it is not based on a particular political configuration. Liberalism must have political legs - in addition to normative appeal - to get any mileage. And the political-strategic conditions that are generally held responsible for the rise of democracy tend to produce electoral rather than liberal democracy.

The crucial building bloc of our analysis is a taxonomy of political regimes, based on a tripartite division of rights: property rights, political rights, and civil rights. We have argued that these rights operate across two fundamental types of cleavage in society: an elite/non-elite cleavage that is largely economic or class-based, and a majority/minority cleavage that typically revolves around the politics of identity. Property rights are important to the elite; political rights empower the majority; and civil rights protect the minority. Liberal democracy requires all three sets of rights, while the bargains that produce electoral democracy generate only the first two.

Democratic transitions rely on the resolution of conflict between the elite and the masses. Our central message is that in the presence of additional cleavages - identity cleavages in particular - this resolution does little, in general, to promote liberal politics. The stars must be aligned just right for liberal democracy to emerge. The rarity of liberal democracy is not surprising. 


\section{REFERENCES}

Acemoglu, Daron, and James Robinson, Economic Origins of Dictatorship and Democracy, Cambridge University Press, Cambridge and New York, 2009.

Bertelsmann Stiftung, Sustainable Governance Indicators: Civil Rights and Political Liberties Report, 2014 (http://www.sginetwork.org/docs/2014/thematic/SGI2014 Civil Rights and Political Liberties.pdf).

Chris Bidner, Patrick Francois, Francesco Trebbi, "A Theory of Minimalist Democracy," unpublished paper, May 2015.

Boix, Carles, Democracy and Redistribution, Cambridge University Press, Cambridge and New York, 2003.

Botero, J. and Ponce, A., "Measuring the Rule of Law," World Justice Project Working Paper No. 2, 2012, available online at www.worldjusticeproject.org.

Chaibong, Hahm, "South Korea's Miraculous Democracy," Journal of Democracy, Volume 19, Number 3, July 2008.

Collier, Ruth Berins, and James Mahoney, "Adding Collective Actors to Collective Outcomes: Labor and Recent Democratization in South America and Southern Europe," Comparative Politics, Vol. 29, No. 3, April 1997, pp. 285-303.

Dahl, Robert, Polyarchy: Participation and Opposition, Yale University Press, New Haven, 1991.

Diamond, Larry, "Facing Up to the Democratic Recession," Journal of Democracy, 26(1), January 2015, pp. 141-155.

Dixit, Avinash, Gene M. Grossman, and Faruk Gul, "The Dynamics of Political Compromise," Journal of Political Economy, vol. 108, no. 3, June 2000, pp. 531-568.

Fatton, Robert, Jr., "Liberal Democracy in Africa," Political Science Quarterly, Vol. 105, No. 3, Autumn 1990, pp. 455-473.

Fawcett, Edmund, Liberalism: The Life of an Idea, Princeton and Oxford: Princeton University Press, 2014.

Fukuyama, Francis, Political Order and Political Decay: From the Industrial Revolution to the Globalization of Democracy, Farrar, Straus and Giroux, New York, 2014.

Goldstone, Richard J., "The South African Bill of Rights," Texas International Law Journal , Vol. 32, No. 3 , Summer 1997. 
Huber, John D., "Inequality and Identity in Electoral Politics," unpublished paper, Columbia University, October 15, 2014.

Inman, Robert P., and Daniel L. Rubinfeld, "Federal Institutions and the Democratic Transition: Learning from South Africa," Journal of Law, Economics \& Organization, 28(4), 2012, 783 -817.

Lehmbruch, Gerhard, "A Non-Competitive Pattern of Conflict Management in Liberal Democracies: The Case of Switzerland, Austria and Lebanon," International Political Science Association, Seventh World Congress, Brussels, 18-23 September 1967.

Levitsky, Steven, and Lucan A. Way, Competitive Authoritarianism: Hybrid Regimes After the Cold War, Cambridge University Press, Cambridge and New York, 2010.

Lijphart, Arend, "Consociational Democracy," World Politics, Vol. 21, No. 2, January 1969, pp. 207-225.

Marshall, T.H., "Citizenship and Social Class," in Jeff Manza and Michael Sauder, eds., Inequality and Society, W.W. Norton, New York, 2009 [original published in 1949].

Mattes, Robert, and E. Gyimah-Boadi, "The Quality of Two Liberal Democracies in Africa: Ghana and South Africa," paper presented at Conference On The Quality of Democracy: Improvement of Subversion?, Stanford University, October 2003.

Moore, Barrington, Jr., The Social Origins of Dictatorship and Democracy, Beacon Press, Boston, 1966.

Müller, Jan-Werner, Contesting Democracy: Political Ideas in Twentieth-Century Europe, Yale University Press, New Haven and London, 2011.

Plattner, Marc F., "Populism, Pluralism, and Liberal Democracy," Journal of Democracy, Volume 21, Number 1, January 2010.

Przeworski, Adam, Democracy and the Market, Cambridge University Press, New York, 1991.

Przeworski, Adam, “Democracy as an Equilibrium," Public Choice, Spring 2005, 253-273.

Rodrik, Dani, “Premature Deindustrialization,” NBER Working Paper No. 20935, February 2015.

Roemer, John E, "Why the Poor Do Not Expropriate the Rich: An Old Argument in New Garb," Journal of Public Economics, vol. 70, 1998, 399-424.

Rueschemeyer, Dietrich, Evelyn H. Stephens, and John D. Stephens, Capitalist Development and Democracy, Chicago University Press, Chicago and New York, 1992. 
Ryan, Alan, The Making of Modern Liberalism, Princeton University Press, Princeton and Oxford, 2012.

Sen, Amartya, "Democracy as a Universal Value," Journal of Democracy, vol. 10, no.3, 1999, 317.

Shayo, Moses, "A Model of Social Identity with an Application to Political Economy:

Nation, Class, and Redistribution," American Political Science Review, vol. 103, no. 2, 2009, 14774.

Somers, Margaret R., "Rights, Relationality, and Membership: Rethinking the Making and Meaning of Citizenship," Law \& Social Inquiry, Vol. 19, No. 1, Winter 1994, pp. 63-112.

World Justice Project, Rule of Law Index, 2015

(http://worldjusticeproject.org/sites/default/files/roli 2015 0.pdf).

Zakaria, Fareed, "The Rise of Illiberal Democracy," Foreign Affairs, November/December 1997. 


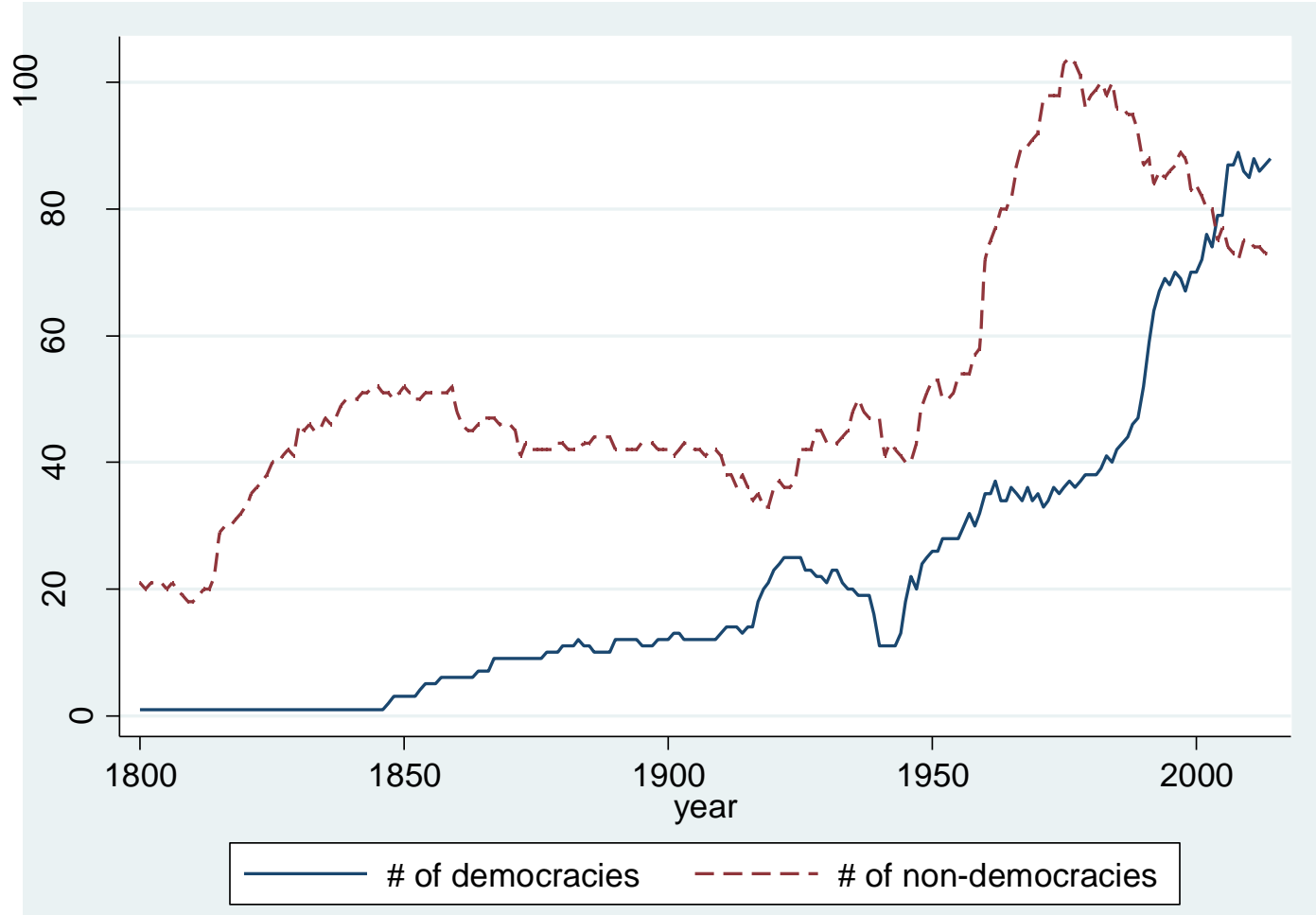

Figure 1: Numbers of democracies and non-democracies since 1800

Note: Data are from Polity IV (http://www.systemicpeace.org/inscrdata.html). "Democracies" are countries that receive a score of 7 or higher in the Polity's democ indicator (which takes values between 0 and 10), while "non-democracies" are countries with a score below 7. 


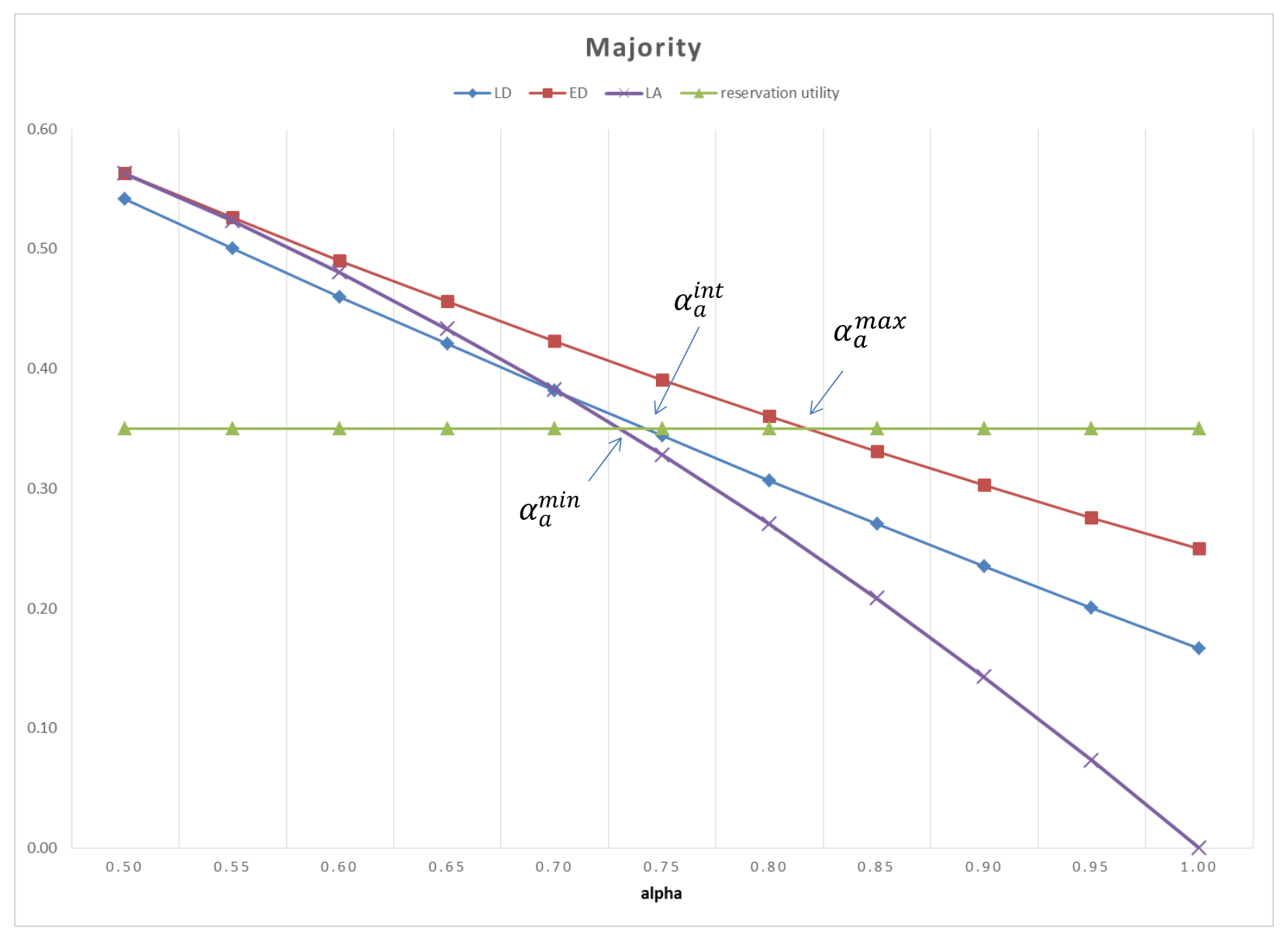

Figure 2: Utility of majority under different political regimes 


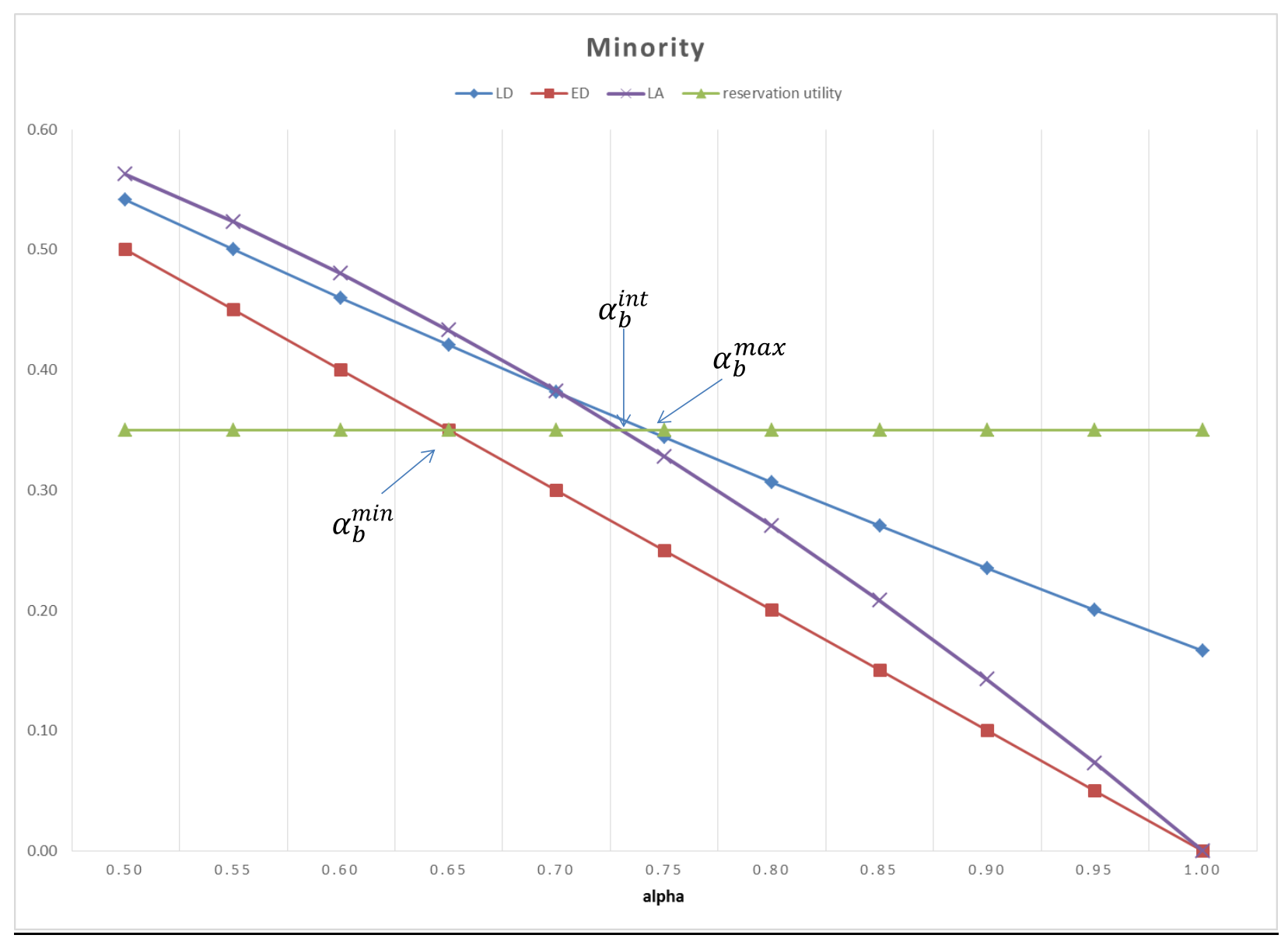

Figure 3: Utility of minority under different political regimes 
$-36-$

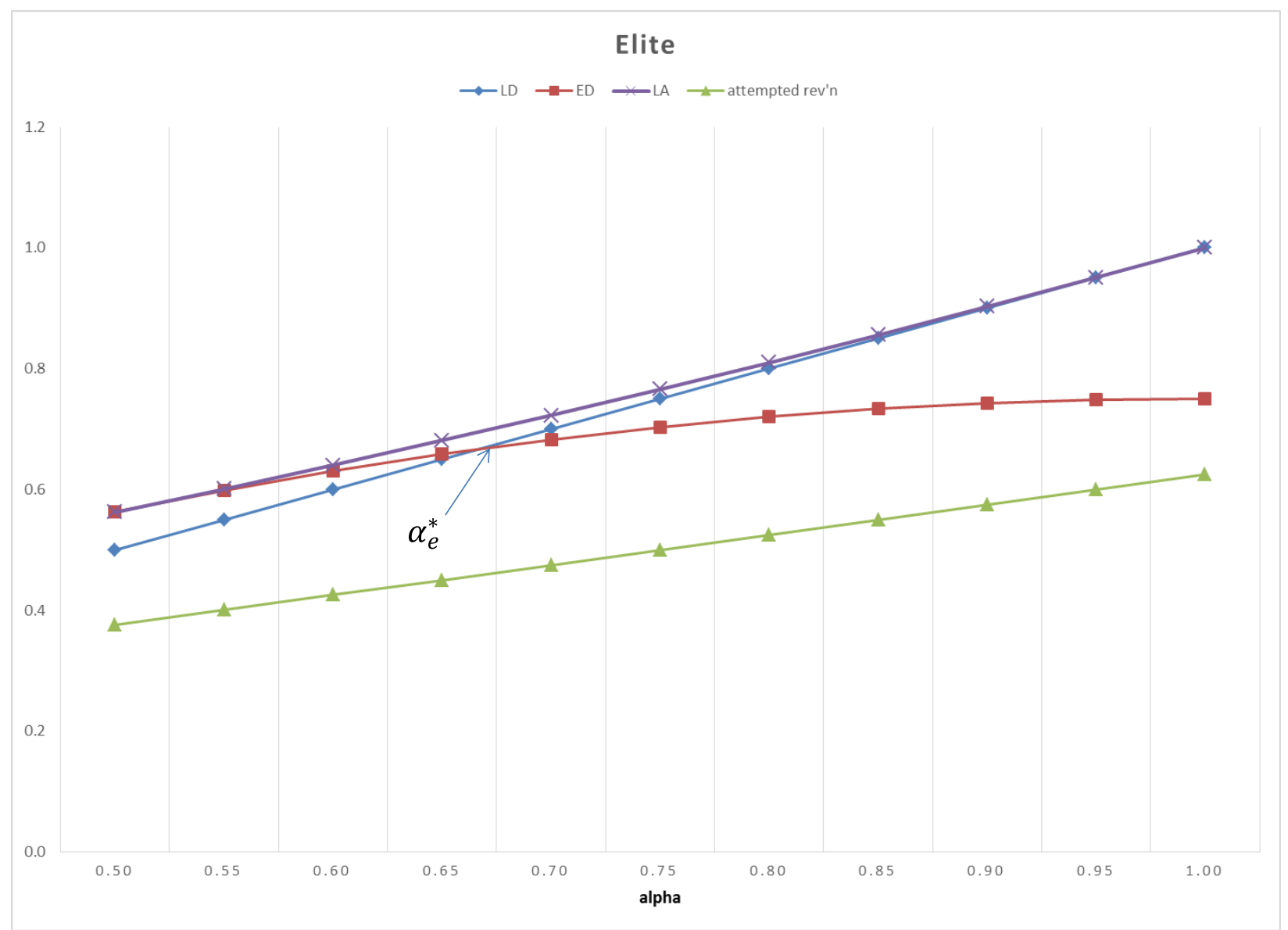

Figure 3: Utility of elite under different political regimes 


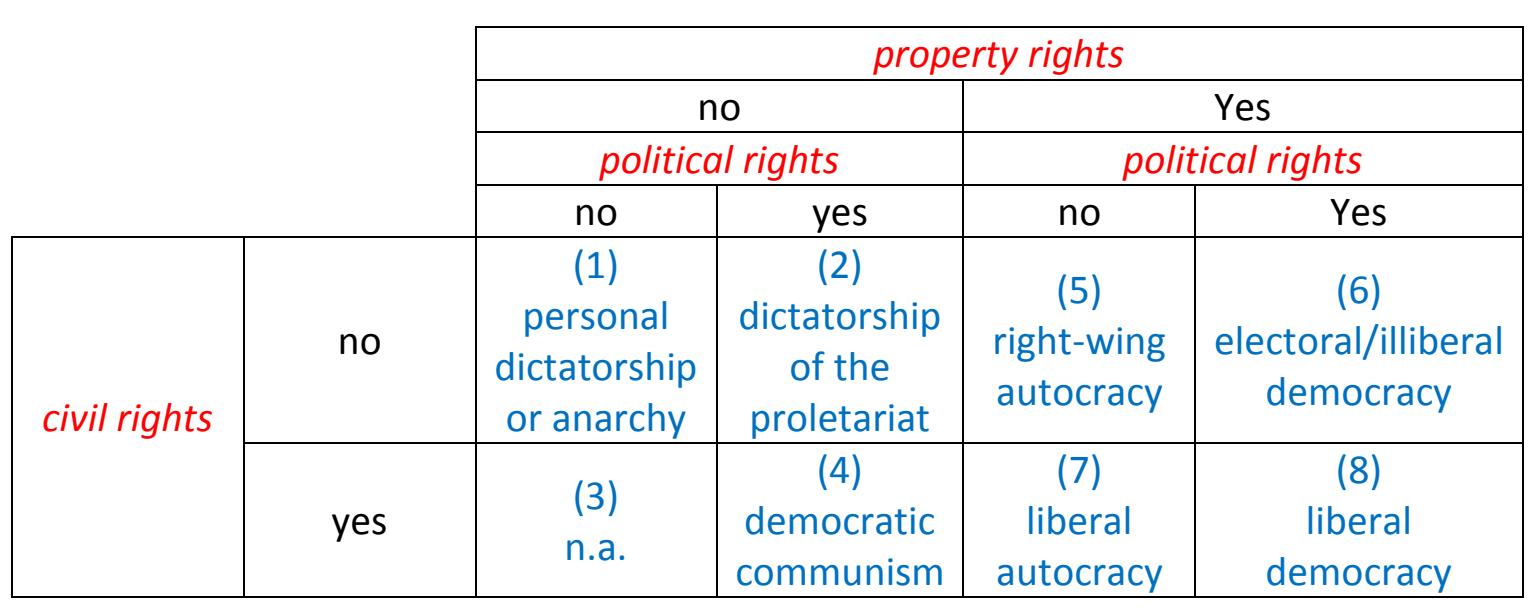




\section{Table 2: Payoffs in equilibria where property rights are protected}

\begin{tabular}{|c|c|c|c|}
\hline & & polit & \\
\hline & & no & Yes \\
\hline \multirow{2}{*}{ civil rights } & no & $\begin{array}{c}\text { (5) } \\
\text { right-wing autocracy (RA) } \\
u_{e}=\alpha+\frac{1}{2 \gamma} \\
u_{a}=(1-\alpha)-\frac{1}{\gamma} \\
u_{b}=(1-\alpha)-\frac{1}{\gamma}\end{array}$ & $\begin{array}{c}\text { (6) } \\
\text { electoral democracy (ED) } \\
u_{e}=\alpha-(2 \alpha-1) \frac{\alpha}{\gamma}+\frac{\theta_{e}}{2 \gamma} \alpha^{2} \\
u_{a}=(1-\alpha)+\frac{1}{2 \gamma} \alpha^{2} \\
u_{b}=(1-\alpha)+\frac{\theta_{b}}{2 \gamma} \alpha^{2}\end{array}$ \\
\hline & yes & $\begin{array}{c}\text { (7) } \\
\text { liberal autocracy (LA) } \\
u_{e}=\alpha+\frac{(1-\alpha)^{2}}{2 \gamma} \\
u_{a}=(1-\alpha)+\left\{(3 \alpha-1)-\left|1-\theta_{e}\right|(1-\alpha)\right\} \frac{1-\alpha}{2 \gamma} \\
u_{b}=(1-\alpha)+\left\{(3 \alpha-1)-\left|\theta_{b}-\theta_{e}\right|(1-\alpha)\right\} \frac{1-\alpha}{2 \gamma}\end{array}$ & $\begin{array}{c}\text { liberal democracy (LD) } \\
u_{e}=\alpha-\frac{(2 \alpha-1)}{(2-\bar{\theta})} \frac{\alpha}{\gamma}+\frac{3-2 \bar{\theta}-\left|\theta_{e}-\bar{\theta}\right|}{2 \gamma(2-\bar{\theta})^{2}} \alpha^{2} \\
u_{a}=(1-\alpha)+\frac{1}{2 \gamma(2-\bar{\theta})} \alpha^{2} \\
u_{b}=(1-\alpha)+\left\{\frac{3-3 \bar{\theta}+\theta_{b}}{2-\bar{\theta}}\right\} \frac{1}{2 \gamma(2-\bar{\theta})} \alpha^{2}\end{array}$ \\
\hline
\end{tabular}

